Many lines have been eradicated. They contained personal comments and details about work on the station and have no interest in this matter whatsoever. The translation is as exact as possible. The only diversion I have allowed myself is to add commas and full stops.

Editor's note: We would like to express our appreciation for the assistance of Michael Gilkes, James Meiklejohn, Sonja Skontorp, Karl Jan Skontorp,-ánd Kristian Flaatten in attaining, 77 years after the event, this answer to a question that has captivated the minds of historians and others interested in the achievements of one of the greatest Antarctic explorers.

\section{Samuel Hearne and the printed word}

\section{I.S. MacLaren}

Canadian Studies Program, University of Alberta, Edmonton, Alberta T6G 2E1, Canada

\section{Received February 1993}

The publication of M.J. Brand's note, 'Samuel Hearne and the massacre at Bloody Falls' (Polar Record 28 (166): 229-232), occasions the need for a delineation of some of the bibliographical aspects of Hearne's famous narrative (Hearne 1795). Rehearsing the well-known story of the massacre on 17 July 1771 of Inuit by Chipewyan and Copper Indians eight miles upstream from the mouth of the Coppermine River, Brand relies on familiar sources for a recapitulation that does not add to or depart from conventional understanding of the event. He follows Glover (1958) in noting that the account of the massacre as published in Hearne's A journey from Prince of Wales's Fort... 'was not part of his original journal (as represented by the Stowe MS)' (Brand 1992: 231). He emphasises that we have Hearne's 'journal' only in the Stowe MS (Hearne 1791a), but he does not state why this is remarkable: perhaps it is because, not being an autograph manuscript, that is, not in Hearne's own hand, the Stowe MS cannot, with utter certainty, be regarded as his work entirely.

Brand does not cite the other published version of the massacre scene (Williams 1969: 196-200), which has appeared since Glover's edition, nor does he mention the other version of the MS (Hearne nd) in the British Library - the Grenville MS in the Dropmore Papers - which has come to light more recently (Smith 1981: 82). This manuscript is also not in Hearne's hand, and may or may not be regarded as closer to the author's exact intentions, depending upon the significance that one accords the information in a comparatively longer title - 'Hearne's journal 1770-72 from the original in possession of the Hudson's Bay Company' - than that of the Stowe MS. It remains to suggest that new ground cannot be broken on this topic without more bibliographical attention being paid to this engrossing omnibus narrative. Following Glover is helpful only to a point, and one does not outdistance that point by following Peter Newman's horrormovie version of the massacre (MacLaren 1991a), which dwells entirely on the element of torture, an element not found in Hearne's field note as it is represented in the Stowe and Grenville MSS. Indeed, any effort to describe the published narrative would do well to begin with Glyndwr William's considered view of the journals of other furtrade explorers: 'It is one of the ironies of the history of the Canadian West that the journals of some of its most significant explorers - Radisson, Kelsey, La France, Pond - present ineluctable problems of reliability and even authenticity' (Williams 1970: 25; 1978: 41).

The relevant section from the transcript of the Stowe MS that was made early in this century for the National Archives of Canada (then the Public Archives of Canada) (Hearne 1791b) has been published (MacLaren 1991b: 30-32), after a check of its accuracy was made, in order to advance the argument that scholars, regardless of discipline, need to pay careful attention to versions of events as different stages of the same narrative give them. A published book faces a different readership and serves a different purpose than does a field note, or a journal written up at the conclusion of exploration for one's company superiors, or even the draft manuscript of the published account. The published book completes the sequence that transforms the traveller/explorer into an author.

In the specific case of the massacre at Bloody Fall, even Hearne's being at the massacre has been doubted, by Franklin's midshipman George Back, who travelled with a man - Annoethai-yazzeh - who had also accompanied Hearne (Houston 1974: 133n; MacLaren 1991b: 46-47). Short of that doubt, admittedly an extreme view although not automatically a dismissable one, one must do what Brand, by following Glover alone, has not done: examine the Stowe and Grenville MSS.

\section{References}

Brand, M.J. 1992. Samuel Hearne and the massacre at Bloody Falls. Polar Record 28 (166): 229-232.

Glover, R. (editor). 1958. A journey from Prince Wales's Fort in Hudson's Bay to the northern ocean 17691770-1771-1772. By Samuel Hearne. Toronto: Macmillan.

Hearne, S. nd. Hearne's journal 1770-72 from the original in the possession of the Hudson's Bay Company. London: British Library, Department of Manuscripts, Dropmore Papers, Grenville MS ADD. 59237.

Hearne, S. 1791a. Mr Hearne's narrative. London: British Library, Department of Manuscripts, Stowe MSS 307: 66-89.

Hearne, S. 1791b. Mr. Hearne's narrative. Transcription of Stowe MS. Ottawa: National Archives of Canada: MG 21, Stowe MS 307 FF-67-89 1791.

Hearne, S. 1795. A journey from Prince of Wales's Fort, in Hudson's Bay, to the northern ocean; undertaken by order of the Hudson's Bay Company, for the discovery of copper mines, a North West Passage, \&c. in the years $1769,1770,1771, \& 1772$. London: A. Strahan and T. Cadell.

Houston, C.S. (editor). 1974. To the Arctic by canoe 18191821: the journal and paintings of Robert Hood, midshipman with Franklin. Montreal and London: McGillQueen's University Press.

MacLaren, I.S. 1991a. Exploring Canadian literature: Samuel Hearne and the Inuit girl. In: Easingwood, P., K Gross, and W. Klooß (editors). Probing Canadian cul- 
ture. Beitrag zur Kanadistik: Band 1. Schriftenreihe der GesellschaftfürKanada-Studien. Augsburg:AV-Verlag: 87-106.

MacLaren, I.S. 1991b. Samuel Hearne's accounts of the massacre at Bloody Fall, 17 July 1771. Ariel: A Review of International English Literature 22 (1): 25-51.

Smith, R.A.H. 1981. The Dropmore Papers (Add. MSS 58855-59494). The British Librany Journal 7 (1): 75-87.

Williams, G. (editor). 1969. Andrew Graham's observations on Hudson's Bay 1767-1791. London: Hudson's Bay Record Society (Publications of the Hudson's Bay Record Society 27).

Williams, G. 1970. Highlights of the first 200 years of the Hudson's Bay Company. The Beaver 301 (autumn): 463.

Williams, G. 1978. The puzzle of Anthony Henday's journal, 1754-55. The Beaver 309 (3): 40-56.

\section{Samuel Hearne and Indian-Inuit hostility \\ Yvon Csonka}

Groupe d'Etudes Inuit et Circumpolaires, Université Laval, Cité Universitaire, Québec, Québec G1K 7P4, Canada

\section{Received December 1992}

In the introduction to 'Samuel Hearne and the massacre at Bloody Falls' (Polar Record 28 (166): 229-232), Michael J. Brand stated that the note 'provides background information and discusses why he [Hearne] was not effective in preventing the massacre' (page 229). Mr Brand later concluded with the comment that 'one cannot blame Hearne' (page 231), one of the primary reasons for the massacre being that 'conflict between the northern Indians and the Inuit was traditional' (page 231). Such a moral vindication of Hearne, however, is not only of questionable historical importance, it also hides questions of a totally different order of significance, including (1) did the massacre take place exactly as one can read it in the published accounts of Hearne's travels, and (2) was it really only one of numerous other such tragedies, another illustration of the commonly accepted opinion that IndianInuit hostility was the rule.

A look at the references cited by $\mathrm{Mr}$ Brand uncovers the fact that much recent literature that could have helped him answer these questions has been ignored. Only two publications more recent than 1975 are quoted, and few would classify Company of adventurers (Newman 1986) as having serious academic ambitions. $\mathrm{Mr}$ Brand failed to cite I.S. MacLaren's 'Samuel Hearne's accounts of the massacre at Bloody Fall' (1991), an article that, although it was written in a literary rather than an ethnographic perspective, covers the same field with much greater background research and analytic acuteness. One is surprised that an author writing a paper on the subject would not have read the Stowe MS and is not aware of another unpublished version of the Bloody Fall massacre quoted by Professor MacLaren. Professor MacLaren's work is convincing in the doubt he casts on the faithfulness of the account attributed to Hearne, in particular the massacre. And Professor MacLaren also discusses the subject of Hearne's reaction to what he saw.

$\mathrm{Mr}$ Brand started from the standardized error of "hostility between the northern Indians and the Inuit was traditional and common' (page 230) to explain the massacre. The first time he made this statement, he cited an outdated source (Speck 1963), and the second time he did not cite any source, as if the statement were indisputable truth, which indicates to me that the comments about Indian-Inuit relations are expressed only to justify Hearne. In doing so, $\mathrm{Mr}$ Brand ignored the most significant contributions to the description and analysis of relations between Athapaskans and Inuit in the central Canadian Arctic and sub-Arctic (for example, Janes 1973; Smith and Burch 1979; Smith 1981). My own contribution to the subject (Csonka 1992) is yet to be published.

It is true that, as stated by $\mathrm{Mr}$ Brand, six Chipewyan were reported to have been killed by Inuit in 1715 , but Smith and Burch (1979: 78) have indicated that the murderers could also have been Cree Indians. As to the 1756 massacre of Inuit by Athapaskans on the west coast of Hudson Bay, Smith and Burch (1979: 81-82, 94-95) discussed at length the different versions of the story extant in the historical sources. The same authors have explained why a simple accumulation of testimonies of hostility and massacres (such as is the case in Mr Brand's note) is methodologically unsound. No one denies that conflicts did occur, but to restrict the analysis of relations between Indians and Inuit to these events distorts reality.

\section{References}

Csonka, Y. 1992. A stereotype further dispelled: the relations between Caribou Inuit and Caribou Eater Chipewyan in the first half of the twentieth century. Unpublished paper presented at the First International Arctic Social Scientists Association Conference, Québec, October 1992.

Janes, R. 1973. Indians and Eskimo contact in southern Keewatin: an ethnohistorical approach. Ethnohistory $20(1): 30-53$.

MacLaren, I.S. 1991. Samuel Hearne's accounts of the massacre at Bloody Fall, 17 July 1771. Ariel: A Review of International English Literature 22 (1): 25-51.

Newman, P.C. 1986. Company of adventurers. Vol. 1. Markham, Ontario: Penguin.

Smith, J.G.E. 1981. Chipewyan, Cree and Inuit relations west of Hudson Bay, 1714-1955. Ethnohistory 28 (2): 133-156.

Smith, J.G.E., and E.S. Burch, Jr. 1979. Chipewyan and Inuit in the central Canadian sub-Arctic, 1613-1977. Arctic Anthropology 16 (2): 76-101.

Speck, G. 1963. Samuel Hearne and the Northwest Passage. Caldwell, Idaho: Caxton. 